Elżbieta Kotkowska ${ }^{1}$

Uniwersytet im. Adama Mickiewicza, Polska

Wydział Teologiczny

\title{
Teologia jako nauka sui generis. W kontekście teologii ks. Franciszka Dziaska
}

\begin{abstract}
Wiara jest podarowanym nam nowym początkiem myślenia, którego my o własnych siłach nie moglibyśmy podjać. Ale równocześnie założenie to mówi, że owa prawda rozjaśnia wówczas cały nasz byt, a więc angażuje też nasz intelekt, chce zostać przezeń zrozumiana. Prawda ta zwraca sie jako prawda do rozumu i musi zostać przezeń pomyślana, by czlowiek ja przyswoit, by mogła rozwinać cała swoją sitę.
\end{abstract}

Joseph Ratzinger ${ }^{2}$

Teologia w kształcie uprawianym na wydziałach teologicznych jest w pełnym tego słowa znaczeniu nauką ${ }^{3}$, ale nie tylko, jest czymś więcej. Jest nauką sui generis, czyli wiedzą zbawczą (scientia salutis) ${ }^{4}$, w której nie chodzi o opracowanie metodyki zbawienia, lecz jak przekonuje ks. Józef Majka, jest to: „kompleks nauk zmierzających do udostępnienia współczesnemu człowiekowi wszystkich treści i owoców wyzwalającego orędzia zbawienia, nadawanie pełnej aktualności i mocy prawdzie, która jedna potrafi człowieka wyswobodzić (J 8,32)"5, prawdzie, którą trzeba aktualizować na każdy czas. Ten swoisty związek wiedzy i mądrości, który należy do istoty teologii, w ciągu wieków w różnym stopniu był ekspono-

${ }^{1}$ Prof. UAM dr hab. Elżbieta Kotkowska - pracownik Zakładu Filozofii i Dialogu Wydziału

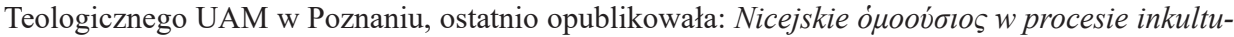
racji wiary w bóstwo Syna. Studium teologicznofundamentalne na tle tradycji, Poznań 2015, „Via, veritas, vita" w perspektywie życia i twórczości o. Pawła Aleksandrowicza Fłorenskiego, Poznań 2016, Utrwalanie przekonań. Ujęcie teologicznofundamentalne i integralne, Poznań 2018; e-mail: elzbieta.kotkowska@amu.edu.pl. ORCID:0000-0001-8807-882X.

2 J. Ratzinger, Prawda w teologii, thum. M. Mijalska, Kraków 2005, s. 63.

${ }^{3}$ Każda z nauk teologicznych ma swoją metodę, por. SNT PAN 2; SNT PAN 3; M. Skierkowski, Powołanie $i$ warsztat teologa. Wprowadzenie do teologii, Tarnów 2012, s. 203-209.

${ }^{4}$ Por. M. Skierkowski, Powołanie i warsztat teologa ..., s. 209-212.

5 J. Majka, Metodologia nauk teologicznych, Wrocław 1981, s. 168. 
wany. Od czasów Abelarda rozpoczął się proces przejścia od doctrina christiana, sacra scriptura, divina pagina czy sacra eruditio do theologia rozumianej jako nauka czysto akademicka. Ujawnił się w dziełach Alberta Wielkiego i Tomasza z Akwinu. Choć obaj silnie podkreślali, że ta nauka jest i powinna być jednocześnie mądrością, to jednak rozpoczął się powolny metodyczny rozdział między teologią a duchowością kształtującą teologa ku mądrości ${ }^{6}$. Ludzki dyskursywny rozum nie jest w stanie opanować paradoksu „związku wiary i wiedzy”", na którym zasadza się teologia. Jest w uprawianiu tej nauki nieusuwalne napięcie pomiędzy werbalizacją relacji z transcendencją ogarnianą ludzkim rozumem, a samą tą relacją określaną jako wiara. Łączy się ona z ludzką postawą moralną wobec Boga, siebie i innych. $\mathrm{Z}$ tego względu wydaje się konieczne przedstawienie nie tylko efektów teologicznych dociekań ks. dra Franciszka Dziaska, ale również kim był, tak by sfera madrościowa uprawianej przez niego teologii mogła się ujawnić.

Recepcję jego myśli wyznaczają końcowe etapy życia. Zmarł w 1971 roku, a wykładowca był w latach 1950-1964, czyli tuż przed zamknięciem obrad II Soboru Watykańskiego zakończył swoją dydaktyczną działalność. Studenci, w trudnych dla wszelkiego rodzaju wydawnictw niekomunistycznych czasach, wydali w wersji powielaczowej wykłady prowadzone dla kleryków Poznańskiego Arcybiskupiego Seminarium Duchownego. Jego główne dzieła z teologii systematycznej udało się opublikować w latach 1959-1970. Powstały cztery obszerne opracowania książkowe:

- Stwórca natury i dawca łaski. Traktat dogmatyczny;

- Jezus Chrystus Boski postaniec. Traktat chrystologiczny;

- Jezus Chrystus Zbawcze misterium. Traktat soteriologiczny;

- Księga życia Bożego. Traktat dogmatyczny o tasce ${ }^{8}$.

Z tych publikacji wynika, że w pierwszym rzędzie poznański teolog uprawiał teologię jako formę poznania rozumowego i naukowego. Był w swoim myśleniu spadkobiercą Alberta Wielkiego i Tomasza z Akwinu. Jego dorobek ukazuje się pełniej na tle całej tradycji teologicznej. Warto też podkreślić jego wierność tradycji związanej z systematyczną teologią sprzed II Soboru Watykańskiego. W pracach poznańskiego teologa nie ma określenia podanego w temacie tegoż artykułu; teologia była

${ }^{6} \mathrm{~W}$ dzisiejszych czasach, po oświeceniowej traumie, co do naukowości wielu nauk, w tym teologii, wracają postulaty łączenia nauki i duchowości, by pełniej wyrazić relację Boga i człowieka. Por. G.L. Müller, Teologia jako nauka, w: M. Rajfur, Nauka zdecydowanie fundamentalna, 22 czerwca 2018, „Gość Niedzielny, wrocławski”, [online] https://wroclaw.gosc.pl/doc/4830812. Nauka-zdecydowanie-fundamentalna [31.05.2019].

7 J. Ratzinger, Prawda w teologii, s. 62.

${ }^{8}$ F. Dziasek, Stwórca natury i dawca taski. Traktat dogmatyczny, Poznań 1959; tenże, Jezus Chrystus Boski postaniec. Traktat chrystologiczny, t. 1, Jezus Chrystus Zbawcze misterium. Traktat soteriologiczny, t. 2, Poznań 1963; tenże, Księga życia Bożego. Traktat dogmatyczny o łasce, Poznań 1970. 
dla niego nauką, ale w swoim wprowadzeniu do teologii przekonywał dlaczego. Stąd jesteśmy w stanie wyłowić te stwierdzenia, które ukazują, czym teologia wyróżnia się spośród innych nauk oraz że to rozróżnienie nie deprecjonuje jej jako nauki ${ }^{9}$.

Kim był poznański teolog jako człowiek szukający mądrości? Studiował przed wojną w Rzymie, na Gregorianum, i tę więź z uczelnią starał się podtrzymywać, choćby przez prenumeratę czasopisma tejże uczelni „Gregorianum”10. Nie ograniczał się w swoim ugruntowywaniu wiedzy tylko do środowiska europejskiego. Prenumerował prestiżowy kwartalnik „Theological Studies” wydawany w Stanach Zjednoczonych. Czytał aktywnie, zamieszczając rozliczne uwagi i notatki na marginesach, tym samym wchodził w swoistą interakcję z treścią artykułów ${ }^{11}$. Był człowiekiem o szerokich horyzontach poznawczych, czytał renomowane polskie czasopisma literackie, miesięcznik Związku Literatów Polskich „Dialog”'12 oraz miesięcznik poświęcony dramaturgii współczesnej, teatralnej, filmowej i radiowej „Twórczość"13. Pierwsze do dziś zajmuje się tematyką dramaturgii współczesnej, a drugie jest miesięcznikiem literackim redagowanym $\mathrm{w}$ tamtym czasie przez Jarosława Iwaszkiewicza. Dzięki osobistym adnotacjom na marginesach artykułów wiemy, że ks. Dziasek znał współczesne dramaty Samuela Becketta, Eugene’a Ionesco, Friedricha Reinholda Dürrenmatta. Był też koneserem muzyki klasycznej. Świadczą o tym kolejne glosa na marginesach tych czasopism. Ale o tym nie wiedzieli studenci/klerycy, jak stwierdza Feliks Lenort, który archiwizował bibliotekę ks. dra Franciszka Dziaska. Dodatkowo podkreślając nurt mądrościowy, konkluduje:

Jego dydaktyka teologiczna wypływała z głębokiej wiary. Wiary wypróbowanej i ugruntowanej w okresie przeżyć i doświadczeń w czasie pogardy. Był [...] wychowawcą wielu pokoleń przyszłych kapłanów. [...] Talentem w tej materii nie był nie na tej płaszczyźnie przecież urzeczywistniała się jego pierwszoplanowa aktywność - ale przy boku ks. Rektora Aleksego Wietrzykowskiego odegrał ważną rolę ${ }^{14}$.

Można powiedzieć, że był niejako ważnym dopełnieniem odpowiedzialnej funkcji księdza Rektora.

\footnotetext{
${ }^{9}$ Por. tenże, Wstęp do nauk teologicznych, Poznań 1958 [druk powielaczowy].

${ }^{10}$ Informacje biograficzne na podstawie F. Lenort, Stowo wstepne, w: F. Dziasek, Pamiętnik czasu pogardy, Poznań 2005, s. 3-20.

${ }^{11}$ Pisze o tym ks. Feliks Lenort, który katalogował księgozbiór i inne dzieła kultury gromadzone przez tegoż kapłana.

12 „Dialog”, 1956- ...; założycielem i pierwszym redaktorem naczelnym był Adam Tarn. Zastępcą redaktora naczelnego w latach 1956-1969 był Konstanty Puzyna.

13 „Twórczość”, 1945- ..; ; w czasach Jarosława Iwaszkiewicza w tym czasopiśmie publikowano współczesną prozę i poezję polską oraz eseje poświęcone literaturze światowej i polskiej. Cennym dorobkiem były też recenzje dzieł literackich.

${ }^{14}$ F. Lenort, Stowo wstęne, s. 19.
} 
Jego postawę, jego duchowość ukształtowały ciężkie przeżycia obozowe w Buchenwaldzie i Dachau, o czym wspomina cytowany jego uczen ${ }^{15}$. W swoim Pamiętniku czasu pogardy niejako rozprawiał się z traumą tamtych czasów. Zapiski ukazują jego wrażliwość na drugiego człowieka, która w nim pozostała również w dalszej pracy naukowej i duszpasterskiej. W 1964 roku napisał artykuł do większej monografii pod tytułem: Pośmiertny los dzieci nie ochrzczonych ${ }^{16}$. Sprawa do dziś jest tematem ważnym, o czym świadczy dokument z czasów Benedykta XVI, Nadzieja zbawienia dla dzieci, które umieraja bez chrztu ${ }^{17}$. W odniesieniu do ks. Franciszka Dziaska artykuł świadczy o wrażliwości na cierpienie matek i ojców, którzy z przyczyn niezależnych od siebie stracili dziecko i nie było możliwości chrztu ${ }^{18}$.

Ksiądz Dziasek zawsze czuł się człowiekiem Kościoła i podkreślał swoistość teologii, o czym przekonuje Feliks Lenort: „[m]ówił niejednokrotnie, że wykład teologiczny, z którego nie bije strumień żywej wiary, będzie raczej erudycyjnym popisem z zakresu wiedzy o religii. Tej głębokiej wiary doświadczaliśmy my, jego dawni uczniowie"19. Jego pierwszoplanową aktywnością było studiowanie i przekazywanie prawd wiary objawionej, w sposób jasny i usystematyzowany. Zadanie, które sobie wyznaczył, szczególnie wobec kleryków seminarium, to wychowywanie ludzi do służby Kościołowi i pewnych swej wiedzy o wierze. Komentatorzy spuścizny ks. Franciszka Dziaska podkreślają przywiązanie do tradycyjnej systematyki obowiązującej w nauczaniu teologicznym do czasów II Soboru Watykańskiego. Feliks Lenort stwierdza:

Reprezentował tradycyjny schemat teologii, zarówno w rozumieniu struktury nauk, jak i jej treści. Można zaryzykować opinię, że w wykładach nie był nowatorem. Uważał, że na płaszczyźnie dydaktycznej należy się opierać na tym, co wypracowano w kolejnych poprzez wieki studiach i syntezach. Podstawowym zadaniem dydaktyki teologicznej w Seminarium Duchownym — mówił — jest ukształtowanie teologicznej i eklezjalnej osobowości przyszłego głosiciela Ewangeliii ${ }^{20}$.

${ }^{15}$ F. Dziasek, Pamiętnik czasu pogardy, Poznań 2005.

16 Tenże, Pośmiertny los dzieci nie ochrzczonych, w: Pod tchnieniem Ducha Świętego, red. M. Finke, Poznań 1964, s. 427-456 [pisownia tytułu oryginalna].

${ }_{17}$ Międzynarodowa Komisja Teologiczna, Nadzieja zbawienia dla dzieci, które umierają bez chrztu, 19 stycznia 2007, thum. J. Królikowski, [online] http://www.vatican.va/roman_curia/congregations/cfaith/cti_documents/rc_con_cfaith_doc_20070419_un-baptised-infants_pl.pdf [31.05.2019].

${ }^{18}$ Znamienne jest, że właśnie po doświadczeniach bestialstwa w czasie II wojny światowej otworzyła się nowa przestrzeń dla ocen teologicznych czynów samobójców i losu dzieci nieochrzczonych.

${ }^{19}$ F. Lenort, Stowo wstępne, s. 19.

20 Tamże, s. 20. Potwierdzają to słowa ks. Tomasza Nawracały: Teologia ks. Dziaska nie była oryginalna. Nie stworzyt poznański profesor jakichś odkrywczych lub przetomowych teorii. Mimo 
Nie oznaczało to jednak zamknięcia w sztywnych i ściśle określonych ramach. Mimo pewnego odgrodzenia od tych, którzy byli powierzeni jego pieczy, potrafił się z nimi dzielić tym, co nowe w teologii. Feliks Lenort, opisując wykłady poznańskiego profesora, przyznaje: „, [s]am jednak był bardzo otwarty na nowe poszukiwania i nimi niejednokrotnie z nami się dzielił, jakby w formie przerywników w męczącym nieraz przydługim dyskursie" ${ }^{21}$. Nie prowadził dyskusji, ponieważ: „[w]yznawał pogląd, że właściwym miejscem dla nowatorstwa teologicznego, jest forum badawcze samych pracowników naukowych tej dziedziny wiedzy"22. Wynikało to z poczucia wielkiej odpowiedzialności, by nie narazić młodych umysłów na zwątpienie. Ks. dr Franciszek Dziasek uznawał pewien ściśle określony porządek rzeczy. Należy mieć wiedzę i warsztat, by odważyć się na nowe poszukiwania, szczególnie w nauce, która jest swoistą wiedzą. Z tego względu można na jego twórczość spojrzeć tak jak na kanony tworzenia ikon i powstałe według tych kanonów dzieło ${ }^{23}$. Tak jak ikonopis pod koniec życia maluje ikonę Przemienienia, tak ks. Franciszek Dziasek uznawał, że każdy teolog chciałby pod koniec aktywności naukowej przedstawić sumę swych przemyśleń na temat łaski, czyli tej żywotnej więzi człowieka z Bogiem. Książka taka ostatecznie powstała na przełomie czasów w Kościele. W swoim przekonaniu ks. Dziasek pisał w duchu II Soboru Watykańskiego: ,[w] moim przekonaniu sposób opracowania prawd objawionych po burzach okresu przejściowego pozostanie jednak taki, jaki został zaprezentowany w tym dziele"24. Co do formy przekazu ta nadzieja ks. Franciszka Dziaska jak na razie się nie ziściła, nawet — niesłusznie — został pominięty w bibliografii na temat laski w książce Dariusza Oko: Łaska i wolność. Łaska w Biblii, nauczaniu Kościoła i teologii wspótczesnej. Nie znaczy to, że jest zupełnie zapomniany. Recepcją jego

to jednak byla otwarta na nowe trendy w myśli kościelnej XX wieku, choć ujmowała je wedtug klasycznej metody wypracowanej w czasach scholastyki. Metoda ta oparta byta przede wszystkim na wyjaśnianiu kwestii zasygnalizowanych w tytule. Cały wywód logiczny opiera się na podaniu argumentów za i przeciw przy jednoczesnym przywołaniu jako decydujacego fragmentu Pisma św. lub myśli jednego z ojców Kościoła. Taki sposób uprawiania teologii był skoncentrowany nie tyle na całościowym ujęciu misterium samego Boga objawiającego się w Chrystusie i działającego dla uświęcenia człowieka przez Ducha Świętego w Kościele, ile na oddzielonym od reszty, choć nie dowolnym, przytaczaniu rozmaitych pytań jako kwestii teologicznych. W ten sposób powstawaty całe ciagi zagadnień, ujmowanych dla spójności w sekcje, które należało — szczegótowo — zapamiętać dla przekazania innym. Ze swojej natury byta więc taka teologia odtwórcza, choć dobrze usystematyzowana, jasna i przejrzysta [materiały niepublikowane].

${ }^{21}$ F. Lenort, Stowo wstępne, s. 20.

22 Tamże.

${ }^{23}$ Wybór takiej analogii potwierdzają opinie ks. Feliksa Lenorta: „Ogromnym zaciekawieniem i zaangażowaniem towarzyszył ożywieniu teologicznemu, które zostało wywołane przez II Sobór Watykański"; tamże.

${ }^{24}$ F. Dziasek, Księga..., s. XII. Ks. Feliks Lenort dodaje: „Niechybnie, istota tej teologii nie uległa zmianie. Po upływie wszakże kilkudziesięciu lat od napisania tych słów, wydaje się, że optymizm autora był jednak nieco nadmierny”; F. Lenort, Słowo wstępne, s. 20. 
twórczości na temat łaski zajmowali się Stanisław Gulak ${ }^{25}$ czy Bonawentura Smol$\mathrm{ka}^{26}$, podkreślając personalistyczny charakter jego wywodów.

Ksiądz dr Franciszek Dziasek pozostawił po sobie przede wszystkim podręczniki i książki ukazujące stan przedsoborowej wiedzy teologicznej w zakresie teologii systematycznej. Uznawał, że studentom/klerykom należy się wykład systematyczny i ugruntowany tego, co Kościół do wierzenia podaje. Studenci powinni poznać dane o swojej wierze w niepodważalnych podstawach jako pewne, wierne i bezbłędne. Dyskurs nad prawdami i recepcją prawd wiary był dla niego możliwy jedynie w gronie akademickich naukowców. Był wyrazicielem postaw z końca XIX i początku XX wieku, że najpierw należy poznać fundamenty, by potem szukać nowych dróg w każdej z dziedzin naukowych ${ }^{27}$. Możemy więc stwierdzić, że zgodnie z wielowiekową tradycją ks. Dziasek widział niepodważalne miejsce teologii na Uniwersytecie. Swój wywód wprowadzający $\mathrm{w}$ teologię, dostępny nam z powielaczowego druku ${ }^{28}$, rozpoczyna tradycyjnie od wythumaczenia nazwy teologia ${ }^{29}$.

\section{Teologia jako nauka}

Na początku XXI wieku, na łamach czasopisma „Nauka” odbyła się dyskusja na temat statusu naukowego teologii, a tym samym jej miejsca $\mathrm{w}$ przestrzeni uniwersyteckiej. W metodologii nauk szczegółowych jak też i w filozofii oraz teologii dokonał się znaczący postęp, który z jednej strony pomaga $w$ interpretowaniu danych z Objawienia, z drugiej zaś coraz większe wyspecjalizowanie narzędzi badawczych w każdej z dziedzin oddala od siebie badaczy otaczającego nas świata i transcendencji. Nawet w ramach samej teologii badacze muszą z pokorą przyznać, że większość jej obszarów jest poza ich kompetencjami jako naukowców $^{30}$. Współcześnie, historyczny rozwój świadomych działań naukowych ludz-

25 S. Gulak, Personalistyczny wymiar taski wedtug Franciszka Dziaska, Sandomierz 2011.

${ }_{26}$ B. Smolka, Elementy personalistyczne nauki Franciszka Dziaska o łasce, „Wrocławski Przegląd Teologiczny" 8/1 (2000), s. 65-75.

${ }^{27}$ Czyli, najpierw poznaj dostępną już wiedzę, następnie szukaj nowych dróg widzenia relacji Bóg-człowiek. Taką drogę też przyjmowali wielcy naukowcy od Picassa po Einsteina. W czasach gdy dynamika osiągnięć naukowych była znacznie mniejsza, tego typu postawa była oczywista. Obecnie już choćby narzędzia badawcze zmieniają się z dekady na dekadę i trudno się dziwić niecierpliwości badawczej naukowców.

${ }^{28}$ F. Dziasek, Wstęp...

29 Analogia w nazewnictwie dyscyplin naukowych podprowadza pod przyjęcie teologii jako nauki. Pomijam recepcję nazwy 'teologia’ w historii chrześcijaństwa.

${ }^{30}$ Por. L. Nowak, Metodologiczne kryterium demarkacji i problem statusu teologii, „Nauka” 3 (2004), s. 121-136; T. Węcławski, Metodologia teologii, „Nauka” 3 (2004), s. 101-120; tenże, Co rozstrzyga o naukowej/metodologicznej odrębności teologii?, „Nauka” 3 (2006), s. 95-109; 
kości w powszechnej, czyli medialnej świadomości praktycznie nie jest znany. Przedstawiciele tak zwanych nauk wyzwolonych, które wyszły z teologicznego myślenia o świecie, domagają się uzasadnienia przypisywanej sobie naukowości od teologii, zapominając o tej, z której wyszły. W ramach tego przedstawienia spróbuję wykazać, że zadania, które wyznaczał teologowi i teologii ks. dr Franciszek Dziasek, są dalej aktualne, choć dzięki postępowi w teologii mamy szerszy wachlarz narzędzi badawczych ${ }^{31}$. Jednak postawa i przekonanie poznańskiego teologa dają przyczynek, by uważać teologię za królowa nauk z jak najbardziej zasadną obecnością na uniwersytetach ${ }^{32}$.

Współcześnie podnosi się kwestię braku ścisłego dookreślenia, czym jest teologia i kim jest teolog. Podstawą problemu jest zagadnienie kościelności tej nauki. Stanowiska rozpościerają się pomiędzy bardzo skrajnymi stwierdzeniami: Robert Rynkowski w tytule swojej książki oświadcza: Każdy jest teologiem. Ale już w podtytule dookreśla, że jest to Nieakademicki wstepp do teologii. $\mathrm{Na}$ drugim biegunie mamy stwierdzenia Jean-Luc Mariona z jego książki Bóg bez bycia, że we właściwym sensie teologiem jest tylko biskup, ze względu na jego eucharystyczne odniesienia i sukcesje apostolską. Pomiędzy tymi stwierdzeniami, wraz z przyjętą w założeniu kościelnością, plasuje się teologia jako nauka i teolodzy ją uprawiający, szczególnie ci świeccy. Ujmowanie treści teologicznych musi mieć odniesienie do wiary Kościoła, i każdy teolog wypowiada się z jej wnętrza. Takie było podstawowe przekonanie ks. Franciszka Dziaska, który przekonuje, że podstawowymi trudnościami w myśleniu o naukowości teologii są jej treść i przedmiot. Już w tym pierwszym przybliżeniu określenie sui generis narzuca się z pewną koniecznością. Ks. Dziasek podkreśla: „[t]reścią roztrząsań teologicznych jest przede wszystkim sam Bóg" ${ }^{33}$. Wszystkie inne zagadnienia, które są rozpatrywane w teologii, mogą być ujmowane tylko wtedy, gdy mają jakiś związek z Bogiem ${ }^{34}$.

Ksiądz Franciszek Dziasek, mając na względzie tego typu odniesienia i dookreślając sposób ujmowania treści teologicznych, zadaje pytanie: „,czy czynność poznawcza rozumu ludzkiego w odniesieniu do Boga może być zaliczana do rzędu

\footnotetext{
A. Bronk, S. Majdański, Teologia — próba metodologiczno-epistemologicznej charakterystyki, „Nauka” 2 (2006), s. 81-110; ciż, Kłopoty z porzadkowaniem nauk: perspektywa naukoznawcza, „Nauka” 1 (2009), s. 47-66; SNT PAN 2; SNT PAN 3.

${ }^{31}$ Szerzej na temat metod stosowanych również w uzasadnianiu naukowego statusu teologii por. K. Kaucha, J. Mastej, M. Rusecki, Metodologia teologii fundamentalnej, Lublin 2019.

${ }^{32}$ M. Skierkowski, Powołanie $i$ warsztat teologa ..., s. 209-212.

${ }^{33}$ F. Dziasek, Wstęp..., s. 1.

${ }^{34}$ Ksiądz Franciszek Dziasek, jako że doktoryzował się w czasach przedwojennych, gdy w seminariach panowała neoscholastyka, stwierdza: „,w teologii scholastycznej treść rozważań nazywa się inaczej przedmiotem materialnym. Stąd można też powiedzieć, że Bóg jest przedmiotem materialnym teologii”; tamże.
} 
czynności naukowych" i werbalizuje tę trudność, którą również w czasach dzisiejszych podnosili naukowcy we wspomnianej wyżej dyskusji w czasopiśmie „Nauka”. „Czy rozpatrywanie Boga z punktu widzenia nadprzyrodzonego ma charakter badania prawdziwie naukowego" ${ }^{35}$ ? Teolog przyznaje, że Bóg jako treść badań naukowych może być ujmowany w dwojaki sposób. W tak zwany sposób naturalny, z pozycji rozumu za pośrednictwem świata stworzonego, co jak stwierdza, jest raczej domeną teodycei. Albo w sposób właściwy Bóg w teologii jest rozpatrywany w świetle objawienia nadprzyrodzonego. Ludzki rozum jest wsparty danymi płynącymi z Bożego objawienia i przez to jego poznanie może być dokładniejsze, przenikliwsze i głębsze. Tym samym ks. Franciszek dookreślił podstawy tak zwanej metody teologicznej. Teolog, pracując na tym samym materiale badawczym co inne nauki, może sięgać głębiej, ponieważ sam Bóg przekazuje człowiekowi samowiedzę, która jest tylko Jemu właściwa. Może formułować przenikliwsze wnioski, dzięki wnikaniu w życie wewnętrzne Trójcy, gdzie objawia się bogactwo życia trynitarnego. Jednocześnie są one dokładniejsze, ponieważ Bóg pozwala ludzkiemu rozumowi zdobywać wiedzę wykraczającą poza jego możliwości.

Warto też przypomnieć, czym jest postępowanie naukowe według ks. Franciszka Dziaska, wobec rozmywania granic współczesnej nauki. Integralność i interdyscyplinarność są wielkim osiągnięciem nauk XX i XXI wieku, ale nie wolno zapomnieć o starożytnej zasadzie logicznej, że ten dobrze rozumie, kto dobrze rozróżnia (bene intelligit, qui bene distinguit). Stąd metoda naukowa domaga się ściśle określonych procedur badawczych często różnych w każdym z obszarów. Poznański teolog przekonuje, że prawa rozumu są w każdej z tych działalności na pierwszym miejscu, co do orzeczenia o naukowości procedur. Wtedy to, co naukowe jest oparte na silnym fundamencie, a zatem jest bezpieczne, pewne i prawdziwe. W każdej nauce ustala się określone założenia i na ich podstawie wyprowadza wnioski. Postępowanie takie musi być metodyczne i systematyczne, co pozwala na układanie poszczególnych twierdzeń w pewien zamknięty i logicznie powiązany system. W ten sposób naukowiec „buduje gmach swojej wiedzy"36. Każda z nauk szczegółowych wznosi się na bazie przyjętych założeń i wywnioskowanych konkluzji, które stają się jej twierdzeniami. Zespół takich twierdzeń tworzy zrąb poszczególnych gałęzi wiedzy. W ten sposób gromadzi się zasób wiadomości popartych logicznym rozumowaniem, ścisłymi dowodami. Ks. Franciszek Dziasek przekonuje, że każda nauka, by mogła zaistnieć, u swych fundamentów potrzebuje niepodlegających dowodzeniu założeń, tak zwanych aksjomatów. Można śmiało powiedzieć, że są one w pewnym sensie aktem wiary, który przyjmujemy jako narzucającą się oczywistość. Poznański teolog zauważa pewną prawidłowość, że wobec nagromadzonych przez wieki twierdzeń

\footnotetext{
35 Tamże, s. 2.
}

36 Tamże, s. 3. 
naukowych i uzasadnionych konkluzji liczba założeń dla nauk spekulatywnych pozytywnych/szczegółowych i humanistycznych jest niewielka, by nie powiedzieć znikoma ${ }^{37}$. Stąd współcześnie zdarzają się, wcale nierzadko, przypadki zapominania o nich, co fałszuje interpretację, prowadząc do zawłaszczeń światopoglądowych $^{38}$. Dla wykładowcy i naukowca umiejętność świadomego rozeznania założeń pierwszych prowadzi do tak zwanej filozofii pierwszej, której założenia legitymują się oczywistością bezpośrednią. To znaczy mają w sobie jasność i oczywistość bezpośrednią, której żaden dowód nie jest w stanie dostarczyć, ponieważ jego zadaniem jest dostarczenie oczywistości pośredniej. Ks. Franciszek Dziasek mocno podkreśla, że nauki działają na zasadzie zapośredniczenia, przez przyjęte jako oczywiste zasady pierwsze. Gmach nauki budowany jest przez układy/zespoły uzasadnionych twierdzeń, które nie zawsze mają bezpośrednie odniesienie do zasad pierwszych, mogą opierać się na wnioskach innych nauk, które on nazywa nadrzędnymi wobec danej nauki. Ich nadrzędność polega na bliższych relacjach z filozofią określaną jako nauka pierwsza. Przekonuje:

zatem w obrębie całej wiedzy ludzkiej, w której grupują się uszeregowane poszczególne gałęzie wiedzy, przyjęcie założeń jest w ostateczności uzasadnione i wskutek tego na forum rozumu usprawiedliwione. Albowiem nawet pierwszy próg, który leży u wstępu do gmachu najogólniejszej wiedzy ludzkiej, (filozofii) przekracza się z olśniewającą jasnością, bo z oczywistością pierwszych zasad ${ }^{39}$.

Według zasad pierwszych działają systemy sformalizowane [logistyka] i dedukcyjne [matematyka], naukowe są też nauki pozytywne i indukcyjne, jak i nauki przyrodnicze, historia i prawo ${ }^{40}$. Tworzywem naukowości jest wiedza zdobywana przez doświadczenie lub działanie rozumu, które leżą w zasięgu ludzkich możliwości i ich kryterium sprawdzalności również w tym obszarze się mieści.

Po tym wywodzie przyjętym dzięki umiarkowanemu realizmowi uznającemu, że człowiek może w sposób rozumny poznawać siebie i świat, ks. Franciszek Dziasek przechodzi do „usprawiedliwienia założeń teologii”. Jasno i wyraźnie stwierdza, że gmachu wiedzy tak zwanej pozytywnej tezy teologiczne nie mogą być sprawdzone przy pomocy doświadczenia czy zasad wnioskowania rozumowego. Poznański teolog wprowadza pojęcie spraw duchowych, niewidzialnych, nadprzyrodzonych, które można sprawdzić i zbadać tylko pod kątem ich praw-

\footnotetext{
${ }^{37}$ Nauki przyrodnicze i humanistyczne, nauki ścisłe i pozytywne/a humanistyczne.

${ }^{38}$ Można też odnieść się do przed-założeń, które każdy naukowiec ma i według których kształtuje swoje widzenie świata, buduje swój gmach nauki. Warto, by miał ich ukonkretnioną świadomość.

39 Tamże, s. 4.

${ }^{40}$ Status nauki mają też wszystkie nauki humanistyczne i społeczne, w tym socjologia.
} 
dziwości dedukcyjnej z przesłanek ${ }^{41}$. Problem przyjmowanych w teologii przesłanek rodzi pytanie, czy są prawdziwe. Artykuły wiary, jak w języku swojej epoki stwierdza ks. Franciszek Dziasek, nie mogą być udowodnione wprost żadnym argumentem naturalnym jako prawdziwe. Teolog zadaje pytania, które ze zdwojoną siłą wróciły w Polsce, gdy część uniwersytetów przyjęła lub utworzyła Wydziały Teologiczne. Pytania te brzmią:

- jak usprawiedliwia teologia fakt przyjęcia założeń, którymi są twierdzenia objawione i jaką posiada rękojmię ich prawdziwość?

- na kogo ma zrzucić teologia obowiązek udowodnienia jej zasad?42

Jasno i wyraźnie teolog stwierdza, że w obrębie świata stworzonego teologowie nie potrafią wskazać takiego argumentu, nie potrafią wykazać wprost prawdziwości założeń pierwszych w teologii, czyli prawdziwości twierdzeń objawionych. Ten stan obiektywnej niemożności nie zniechęca teologa i pyta dalej: „[a] może prawdziwość założeń teologii dałoby się zdobyć na innej drodze. Może istnieje droga choćby okrężna, która by w rezultacie doprowadziła do tego samego upragnionego celu?" ${ }^{43}$. Przytacza trzy drogi prowadzące ku opisanemu celowi, każda z nich wymaga tak zwanego nieuprzedzonego rozumu. Określa je jako rozwiązanie tomistyczne, dalej tłumaczenie chrystologiczne i uzasadnienie apologetyczne.

Teologia w czasach ks. Franciszka Dziaska była w silnych relacjach z filozofią i teologią św. Tomasza z Akwinu, stąd pierwsza argumentacja prowadzi teologa do widzenia naukowości teologii w jego interpretacji. Status teologii wyznaczają jej źródła niezaczerpnięte z ludzkich działań, ale z wiedzy samego Boga i tych, którzy są już zbawieni. Stąd uzasadnienie założeń teologii otrzymuje horyzont eschatyczny, niemożliwy do falsyfikacji w doczesności. W przytoczonej dyskusji w czasopiśmie „Nauka” to uzasadnienie założeń i możliwości sprawdzalności badań naukowych teologii jest najsilniej kontestowane, szczególnie, że w obecnych czasach obserwujemy zanik wyobraźni eschatologicznej w społeczeństwach euroatlantyckich.

W uzasadnieniu chrystologicznym teolog zwraca uwagę na Jezusa Chrystusa jako źródło danych dla teologii. On jako Syn Boży wie, co objawia, i teolog, wierząc w jego posłannictwo, odwołuje się do jego wiedzy. Kościołowi, który jest właściwym środowiskiem teologii, pozostaje zawierzyć. Według teologa jest to w istocie podobny akt wiary, dzięki któremu nauki zawierzają wynikom badań nauk dla nich nadrzędnych. Ale podkreśla, że istnieje podstawowa i zasadnicza

${ }^{41}$ W tym względzie każdy zajmujący się badaniami naukowymi i sprawnie wykorzystujący odpowiednie narzędzia poznawcze może ocenić naukowość działań teologów.

42 Tamże, s. 5.

43 Tamże. 
różnica. W naukach opartych na ludzkim rozumie każda $\mathrm{z}$ nadrzędnych nauk uprawiana jest przez człowieka. W teologii u źródeł jej jako nauki leżą słowa i czyny człowieka, który wie, że jest Bogiem. Przekazywane po ludzku prawdy objawione są dla niego oczywistością. Apostołowie są odbiorcami tych źródłowych prawd i teologia opiera się na ich wierze w ich prawdziwość. Stąd teolog w ramach doczesności nie ma możliwości w pełni na sposób rozumu wykazać, czy usprawiedliwić swoje dociekania. Artykułów wiary nie da się wprost udowodnić czy obalić, tak jak twierdzeń w ludzkich naukach. „Stąd z punktu widzenia rozumowego naukowy charakter teologii w tym thumaczeniu chrystologicznym miałby jakby margines pewnego niedomówienia"44. Ale jak stwierdza poznański teolog, są również takie nauki szczegółowe, które z jakimiś niedopowiedzeniami funkcjonują bez sprzeciwów jako naukowe. Nie podaje jednak konkretnych przykładów.

Uzasadnienie apologetyczne źródeł teologii według ks. Franciszka Dziaska wiąże się z przedstawieniem tak zwanej drogi pośredniej. Uznaje, że apologetyka ma prawo formułować tego typu wnioski, ponieważ uzasadnia prawdziwość objawienia. Stwierdza: [apologetyka w]ykazuje mianowicie argumentami sam fakt podania przez Boga ludziom objawienia, skoro pewna jest ta okoliczność, że ściśle określony zespół twierdzeń sam Pan Bóg ludziom przekazał, wówczas w świetle zasad rozumowych jasnym jest, że muszą to być twierdzenia prawdziwe" ${ }^{45}$. We współczesnej apologetyce tak dobitnie przekonujące sądy nie są już formułowane, jednak jeżeli argumenty związane $\mathrm{z}$ wiarygodnością będą przekonujące, to uznanie prawd objawionych stanie się prawdopodobniejsze. Teologia ma prawo odwoływać się do prawd, których wiarygodność bada, tak by w jak największym stopniu oddalić zarzut samopotwierdzania własnych tez i wniosków.

\section{Przymioty naukowego badania}

Ksiądz Franciszek Dziasek formułuje też przymioty badania naukowego, by wykazać, że działania teologów zajmujących się nauczaniem i badaniem na poziomie uniwersyteckim nie odbiegają od zabiegów przedstawicieli innych nauk. Poznański teolog stwierdza, że nauki reprezentujące wiele gałęzi poznania można uszeregować według stopnia ścisłości dowodzenia ich twierdzeń. W każdej z nich muszą być zachowane cechy świadczące o ich naukowości. Przyjmuje klasyfikację, w której metodyczność i systematyczność oraz sprawdzalność i oczywistość stanowią o naukowym statusie danej dziedziny wiedzy. Według jego metodologii wiedzy:

\footnotetext{
${ }^{44}$ Tamże, s. 7.
}

45 Tamże. 
metodyczność polega na dostosowanym do danej dyscypliny sposobie zdobywania i uzasadniania nowych sądów i twierdzeń. Każda z nauk ma swoją metodykę, dzięki której rozszerza i pogłębia krąg swojego poznania. Wybrana metoda uwarunkowana jest założonym wstępnie celem, a naukowiec może i ma prawo stosować najróżniejsze metody, by ten cel osiągnąć lub wykazać niemożliwość jego osiągnięcia;

systematyczność $\mathrm{w}$ pewnym sensie jest odmianą i rezultatem metodyczności. Dzięki niej owoce logicznego działania układają się w powiązaną całość, którą stanowi system naukowy. Umiejętność świadomego wyboru w tym kierunku dalszych badań według logicznie uszeregowanych owoców poznania świadczy o systematyczności badania naukowego;

sprawdzalność danej nauki związana jest z oczywistością, ponieważ dotyczy poprawności przeprowadzonego rozumowania. Przez sprawdzenie poprawności rozumowania dokonuje się weryfikacji prawdziwości samego wniosku. Jeżeli przyjmujemy jakieś przesłanki za prawdziwe i rozumowanie z nich też jest prawidłowe, to i wnioski mają ten sam status prawdziwości, co przyjęte przesłanki. Taką pośrednią rękojmię prawdziwości musi mieć każda nauka;

oczywistość jest bardzo ważną cechą badań naukowych. Przymusza naukowców do formułowania argumentów, które doprowadzają rozum do przyjęcia przedstawianych twierdzeń. Im większa jest siła argumentu tym łatwiej rozumowi rozeznać, czy przynależność orzeczenia i podmiotu zdania jest dla niego oczywista. Oczywistość może być podwójna bezpośrednia i pośrednia.

Zdanie bezpośrednio oczywiste dla ks. Franciszka Dziaska to zdanie, w którym relacje pomiędzy podmiotem i orzeczeniem są oczywiste. Tego typu zdania przyjmowane są bez dowodów, ponieważ ich jasność narzuca się z większą siłą niż wyrazistość, której mogłyby dostarczyć kolejne argumenty. Twierdzenia pośrednie natomiast powstają, gdy rozum widzi zależność orzeczenia od podmiotu przy pomocy przesłanek oraz przy pomocy procesu nazywanego wynikaniem. W tego typu rozumowaniu mamy podwójną oczywistość: oczywistość wyniku i oczywistość wynikania. Dzięki tym działaniom nauka może czerpać swoje założenia od innej nauki nadrzędnej. Musi jednak się troszczyć, by jej założenia były słuszne i prawdziwe, a prawdziwość tych założeń udowadnia nauka nadrzędna, czego nie można zapewnić w naukach teologicznych.

Jednak teologia tak jak inne nauki dba i troszczy się o swoje zasady, a prawdziwość artykułów wiary zostaje poręczona, dziś powiedzielibyśmy podparta argumentami wiarygodnościowymi, przez teologię fundamentalną. Dla poznańskiego teologa jest to sposób wykazania i wykazywania prawdy pośredni, ale solidny i bezpieczny, i tylko taki dostępny jest żyjącemu w doczesności człowiekowi. 


\section{Naukowy charakter teologii}

Ksiądz Franciszek Dziasek konkluduje: teologia jest nauką, w sensie dosłownym, ponieważ nosi w sobie cechy naukowego badania. Urzeczywistnia w sobie wszystkie wspomniane wyżej cechy nauki prawdziwej. Wykazuje wybitne znaki ścisłej metodyczności. Wszystkie z nauk teologicznych mają je wypracowane przez wieki, szczególnie dogmatyka, teologia biblijna, moralna i ascetyczna. Jeśli chodzi o systematyczność jako cechę naukowości w naukach teologicznych, to rezultaty poznania zebrane są w systemy już od czasów ojców Kościoła. Teolog podkreśla, że oczywistość teologii to oczywistość wynikania, czyli przyjmuje do swojego systemu tylko to, co w sposób poprawny i oczywisty wynika $\mathrm{z}$ objawienia Bożego, w tym sensie możemy powiedzieć, że jest nauką sui generis. Jak podsumowuje ks. Franciszek Dziasek, teologia „nie posiada, co prawda w swym dociekaniu oczywistości wyniku, ale ta nie jest cechą istotna i konieczną dla nauki" "'. Dalej przekonuje, że są nauki, które działają na wysokim stopniu abstrakcji i opracowują hipotezy, których wyniki nie są oczywiste, a jednak uznawane w świecie nauki.

Sprawdzalność w naukach teologicznych jest połączona z pewnikami wiary i proces ten może być w pełni sprawdzony. Nie ma jednak możliwości bezpośredniego stwierdzenia sprawdzalności twierdzeń czysto teologicznych, ale ten rodzaj sprawdzalności w wielu naukach również jest niedostępny.

Podsumowując, w rozumieniu ks. Franciszka Dziaska teologia, ponieważ jest nauką opartą na objawieniu, jest nauką, ale współcześnie możemy dodać sui generis, ponieważ przedmiotem jej zainteresowań jest treść Objawienia, stąd pracę teologiczną można skategoryzować według czterech punktów.

1. Teologia sama w sobie rozpatruje fundamenty, na których stoi. Pragnie wydobyć z Pisma Świętego i tradycji sens prawd objawionych. Tu jest wielka praca egzegetów i historii dogmatów [teologia pozytywna].

2. W teologii zależy na ustaleniu właściwego sensu poszczególnych zdań objawionych w Piśmie Świętym i tradycji uwzględniających całość Objawienia. Chodzi o systematyzację danych, według grup, działów myślowych, tak by uchwycić ich kontekst historyczny i potrzeby katechizacji w danym czasie. Prawdy rozrzucone w różnych miejscach trzeba ukazać według ich powiązania i wzajemnego podporządkowania.

3. Na tej bazie trzeba dokonywać wyprowadzania dalszych wniosków i konkluzji, które spełniają rolę przesłanek w rozumowaniach i prowadzą ku odkryciu nowych prawd. Jest to najwłaściwsze zadanie teologii, która wydobywa nowe prawdy wysiłkiem rozumu. Są to cenne cegiełki „gmachu wiedzy teologicznej”.

46 Tamże, s. 12. 
4. Teologia musi wreszcie zmierzyć się z tym, że Objawienie stawia też ludzki rozum wobec faktów i zjawisk, które domagają się wytłumaczenia. Rozum ludzki pragnie powiązać objawione prawdy, które zostały podane w oderwaniu, zarówno z innymi prawdami wiary, jak i ze znanymi zasadami rozumowymi. W tym punkcie według ks. Franciszka Dziaska „rozpościera się szerokie pole dla konstruowania teorii teologicznych"47.

Ostatecznie należy stwierdzić, że ks. dr Franciszek Dziasek dzięki odniesieniu do prawd pierwszych i pojęciu nauk nadrzędnych, które zasadzają się na oczywistościach czy zasadnych przed-sądach opartych na autorytetach ${ }^{48}$, może przekonywać, że teologia jest nauką i dalej „królową nauk”49. Trzeba silnie podkreślić, że jego główna argumentacja opiera się na zasadach pracy teologa w czasach przed II Soborem Watykańskim. Jednakże ukazane w pierwszej części artykułu jego życiowe drogi pokazują, że był człowiekiem, w którym widzimy zgodność czynów, postaw i głoszonych słów. W tym sensie zatem głoszona przez niego teologia ukazuje wiarygodność Objawienia.

\section{Theology as science of sui generis. In the context of Reverend Franciszek Dziasek's theology}

\section{Summary}

Rev. Franciszek Dziasek, S.Th.D. was a lecturer of the Archbishop's Seminary in Poznan from 1950 to 1964. In his lectures, Introduction to Theological Sciences, step by step he justifies claims of theology to be science in the university sense. From the reception of his lectures we learn that he was living with what he preached. In the integral view of the two realities, [theologian and his knowledge] we are shown a trait of theology wisdom, which shows its specificity as the queen of sciences. A Poznan lecturer argues that theology is a science in the ordinary sense of the word. It is also the science of sui generis, because it derives its data from a revelation that is credible in the community of the Church.

\section{Keywords}

Rev. Franciszek Dziasek, S.Th.D., theology, science, sui generis

\section{Słowa kluczowe}

ksiądz dr Franciszek Dziasek, teologia, nauka, sui generis

47 Tamże, s. 13.

${ }^{48}$ H.G. Gadamer, Prawda i metoda, thum. B. Baran, Warszawa 2004, s. 373.

${ }^{49}$ Por. M. Skierkowski, Powołanie i warsztat teologa ..., s. 209-212. 


\section{Bibliografia}

Bronk A., Majdański S., Kłopoty z porządkowaniem nauk: perspektywa naukoznawcza, „Nauka” 1 (2009), s. 47-66.

Bronk A., Majdański S., Teologia - próba metodologiczno-epistemologicznej charakterystyki, „Nauka” 2 (2006), s. 81-110.

Dziasek F., Jezus Chrystus Boski postaniec. Traktat chrystologiczny, t. 1, Jezus Chrystus Zbawcze misterium. Traktat soteriologiczny, t. 2, Poznań 1963.

Dziasek F., Księga życia Bożego. Traktat dogmatyczny o łasce, Poznan 1970.

Dziasek F., Pamiętnik czasu pogardy, Poznań 2005.

Dziasek F., Pośmiertny los dzieci nie ochrzczonych, w: Pod tchnieniem Ducha Świętego, red. M. Finke, Poznań 1964, s. 427-456.

Dziasek F., Stwórca natury i dawca łaski. Traktat dogmatyczny, Poznań 1959.

Dziasek F., Wstep do nauk teologicznych, Poznań 1958 [druk powielaczowy].

Gadamer H.G., Prawda i metoda, thum. B. Baran, Warszawa 2004.

Gulak S., Personalistyczny wymiar taski wedlug Franciszka Dziaska, Sandomierz 2011.

Kaucha K., Mastej J., Rusecki M., Metodologia teologii fundamentalnej, Lublin 2019.

Lenort F., Słowo wstępne, w: F. Dziasek, Pamiętnik czasu pogardy, Poznań 2005, s. 3-21.

Majka J., Metodologia nauk teologicznych, Wrocław 1981.

Międzynarodowa Komisja Teologiczna, Nadzieja zbawienia dla dzieci, które umieraja bez chrztu, 19 stycznia 2007, thum. J. Królikowski, http://www.vatican.va/roman_curia/congregations/cfaith/cti_documents/rc_con_cfaith_doc_20070419_un-baptised-infants_pl.pdf [dostęp: 31.05.2019].

Müller G.L., Teologia jako nauka, w: M. Rajfur, Nauka zdecydowanie fundamentalna, 22 czerwca 2018, „Gość Niedzielny, wrocławski”, https://wroclaw.gosc.pl/ doc/4830812.Nauka-zdecydowanie-fundamentalna [dostęp: 31.05.2019].

Nowak L., Metodologiczne kryterium demarkacji i problem statusu teologii, „Nauka” 3 (2004), s. 121-136.

Oko D., Łaska i wolność. Łaska w Biblii, nauczaniu Kościoła i teologii wspótczesnej, Kraków 1997.

Ratzinger J., Prawda w teologii, thum. M. Mijalska, Kraków 2005.

Skierkowski M., Powolanie i warsztat teologa. Wprowadzenie do teologii, Tarnów 2012.

Smolka B., Elementy personalistyczne nauki Franciszka Dziaska o łasce, „Wrocławski Przegląd Teologiczny" 8 (2000) 1, s. 65-75.

SNT PAN 2 - Studia Nauk Teologicznych PAN, t. 2: Metodologia teologii, red. M. Rusecki, Lublin 2007.

SNT PAN 3 - Studia Nauk Teologicznych PAN, t. 3: Teologia na uniwersytecie, red. M. Rusecki, Lublin 2008.

Węcławski T., Co rozstrzyga o naukowej/metodologicznej odrębności teologii??, „Nauka” 3 (2006), s. 95-109.

Węcławski T., Metodologia teologii, „Nauka” 3 (2004), s. 101-120. 